\title{
A Review of Wind Project Financing Structures in the United States
}

\author{
Mark Bolinger, Lawrence Berkeley National Laboratory \\ John Harper, Ze-gen, Inc. \\ Matt Karcher, Deacon Harbor Financial, L.P.
}

This article is adapted from a longer Berkeley Lab report [1] that was funded by the Office of Energy Efficiency and Renewable Energy, Wind \& Hydropower Technologies Program of the U.S. Department of Energy under Contract No. DE-AC02-05CH11231.

\begin{abstract}
The rapid pace of wind power development in the U.S. over the last decade has outstripped the ability of most project developers to provide adequate equity capital and make efficient use of project-related tax benefits. In response, the sector has created novel project financing structures that feature varying combinations of equity capital from project developers and third-party taxoriented investors, and in some cases commercial debt. While their origins stem from variations in the financial capacity and business objectives of wind project developers, as well as the risk tolerances and objectives of equity and debt providers, each structure is, at its core, designed to manage project risk and allocate federal tax incentives to those entities that can use them most efficiently. This article surveys the six principal financing structures through which most new utility-scale wind projects (excluding utility-owned projects) in the U.S. have been financed from 1999 to the present. These structures include simple balance-sheet finance, several varieties of all-equity special allocation partnership "flip" structures, and two leveraged structures. In addition to describing each structure's mechanics, the article also discusses its rationale for use, the types of investors that find it appealing and why, and its relative frequency of use in the market. The article concludes with a generalized summary of how a developer might choose one structure over another.
\end{abstract}

\section{Introduction}

Wind power capacity in the United States has grown substantially in recent years (Figure 1). From 1999 through 2007, roughly 15 gigawatts ("GW") of new wind capacity were added, accounting for $89 \%$ of the $16.9 \mathrm{GW}$ cumulative total capacity as of the end of 2007. In 2007 alone, roughly $5.3 \mathrm{GW}$ of new wind capacity was installed, representing a $46 \%$ increase in cumulative capacity. For the third consecutive year, this made wind power the second-largest new resource added to the U.S. electrical grid in capacity terms, well behind new natural gasfired plants, but ahead of coal.

This rapid expansion has required the mobilization of a tremendous amount of capital to finance wind project costs. Roughly $\$ 28$ billion (in real 2007 dollars) has been invested in wind project installation in the U.S. since the 1980s, with about \$9 billion invested in 2007 alone [2]. 
Looking ahead, wind project developers will need to raise upwards of $\$ 12$ billion in 2008 in order to finance the $6 \mathrm{GW}$ expansion expected by many, and the required amount of capital will likely continue to increase in future years if market growth continues.

Accessing sufficient amounts of capital to finance the build-out of wind project pipelines has historically been a challenge for many wind developers, due in large part to the importance of Federal tax incentives to a wind project's return. Specifically, qualifying commercial wind projects are eligible to receive a 10-year stream of Federal production tax credits ("PTCs"), and can also depreciate (for tax purposes) roughly $95 \%$ of project assets using an accelerated 5-year schedule. These two major Federal tax incentives, described in more detail in Boxes 1 and 2, are collectively referred to in this article as the project's "Tax Benefits." As a general rule of thumb, investor returns from a wind project often derive as much or more from these combined Tax Benefits than from cash revenue from the sale of power and renewable energy credits ("RECs"). ${ }^{1}$

\section{Box 1: The Federal Production Tax Credit}

As authorized by the Energy Policy Act of 1992 and amended over time, Section 45 of the Internal Revenue Code provides a production tax credit for power generated by certain types of renewable energy projects, including wind power. For wind, the PTC provides an inflation-adjusted $1.5 \varnothing$ per kilowatt hour ("kWh") credit for a 10-year period (the credit amount varies for other renewable power technologies). For 2008, the inflationadjusted PTC rate stood at $2.1 \notin / \mathrm{kWh}$.

Since its original expiration in mid-1999, the PTC has subsequently expired and been re-instated or extended several times (the credit is currently available to projects placed in service before the end of 2008). These frequent expirations and shortterm extensions have contributed to the boom-bust development cycle from 1999-2004 exhibited in Figure 1.

\section{Box 2. Accelerated Tax Depreciation}

Section 168 of the Internal Revenue Code provides a Modified Accelerated Cost Recovery System ("MACRS") through which certain investments in wind (and many other types of) projects can be recovered through accelerated income tax deductions for depreciation. Under this provision, which has no expiration date, certain wind project equipment - including the turbines, generators, power conditioning equipment, transfer equipment, and related parts up to the electrical transmission stage - may qualify for 5-year, 200 percent (i.e., double) declining-balance depreciation. A typical rule of thumb is that $90-95 \%$ of the total costs of a wind project qualify for 5-year MACRS depreciation, with much of the remaining basis depreciated over 15-20 years.

Historically, most wind project developers have been small, single-purpose entities without a tax base of sufficient size to make efficient use of the Tax Benefits generated by a wind project. As a result, up until about 2003, one of the few options available to such developers was to develop a project up to the point of construction and then sell it to a larger entity (e.g., FPL Energy) with not only access to the capital required to build the project, but also a tax base large enough to efficiently use the project's Tax Benefits.

More recently, as the market has grown and matured, the wind sector has developed multiple financing structures to attract various types of investors to projects (while also allowing developers to maintain an ongoing ownership stake), manage project risk, and allocate Tax Benefits to entities that can use them most efficiently. Some of these structures are intended to attract large, actively involved equity investors with a strategic interest in the wind sector, labeled here as "Strategic Investors." Others are designed to tap into more-passive equity capital from "Institutional Investors," which are primarily interested in the Tax Benefits. Still others enable developers and investors to layer on debt financing to leverage their equity exposure and returns. 
The purpose of this article is to describe in some detail the six principal financing structures through which most new utility-scale wind projects (excluding utility-owned projects) in the U.S. have been financed from 1999 to the present. The year 1999 is used as a starting point because it marks the advent of the recent expansion in wind power growth in the U.S. (see Figure 1). In addition to describing each of these structures both textually and schematically, this article discusses each structure's rationale for use, the types of investors that find it appealing (and why), and its relative frequency of use in the market. The article concludes with a generalized summary of how a developer might choose one structure over another.

Before proceeding, it is worth noting that this article is relevant primarily to the U.S. wind power market, where the presence and structure of the Tax Benefits have driven the development and use of financing structures in ways that are not directly applicable to wind projects located in other countries.

\section{Description of Current Financing Structures}

The six structures described in this section feature varying combinations of equity capital from project developers, third-party tax-oriented investors (both Strategic and Institutional Investors, jointly known as "Tax Investors"), and commercial debt. The first four structures covered are all-equity structures (at least at the project level), while the last two add project leverage. Their origins stem from variations in the financial capacity and strength, as well as the business objectives, of wind project developers. Although one or another of these structures has been used to finance the initial costs of most new utility-scale wind projects in the United States from 1999 to the present, the list of structures covered in this article is not intended to be comprehensive. Various permutations of these structures, as well as other financing mechanisms altogether, are possible. ${ }^{2}$

Before proceeding, it should be noted that the authors are not attorneys or accountants, and the information presented herein - though believed to be compliant with IRS safe harbor guidelines for wind energy partnerships provided in Revenue Procedure 2007-65 [3] - should not be considered as formal legal or accounting advice. Project developers and investors are strongly encouraged to seek qualified tax and accounting counsel prior to structuring a particular project.

\subsection{Corporate Structure}

The Corporate structure is one of the most widely used in the wind sector, and also represents the simplest way to own and operate a project. It is characterized by a single developer with the financial strength to fund all of the project costs and sufficient tax appetite to use all of the project's Tax Benefits. No additional investors or limited-recourse debt financing are involved (at least initially) at the project level.

Figure 2 provides a schematic representation of the Corporate structure. Entities are identified by bold print (the Corporate parent and a special-purpose project company set up to house the project assets). Shaded boxes represent the three types of financial benefits accruing from the wind project: distributable cash, taxable losses/gains, and PTCs. The underlying boxes with percentages show how the respective financial benefits are allocated to the investors (in this case, 
there is only one developer/investor). The project company generates both cash revenue and PTCs from the sale of electric power (it may also generate cash revenues from REC sales). Operating expenses are deducted from revenues to generate cash available for distribution. Taxdeductible expenses (principally depreciation in this structure, though interest on debt would also fall into this category) generate taxable losses, which can be used to offset taxable gains from other operations. Since there is just one investor, the Corporate parent funds $100 \%$ of the project costs as equity in the project company, and in return receives $100 \%$ of the distributable cash, taxable losses or gains, and PTCs generated by the project.

The advantage of this structure relative to others is its simplicity. Funding, accounting, and management issues are not complicated by the need to inform or seek approval from lenders or other investors. As such, this structure is the most time-efficient and incurs the least amount of transaction costs. In the wind sector, these attributes have enabled large developers using this structure to secure competitive advantage. For example, the repeated expirations of the PTC earlier in the decade forced developers to focus their efforts on projects most likely to be completed prior to the next expiration date (since PTC renewal is never guaranteed). Without the need to identify and negotiate for third-party capital, developers able to use the Corporate structure have enjoyed more flexibility and time to complete their projects. In effect, the Corporate structure enables decisions on project development to be separate from decisions about the best means to finance the project; it allows the parent investor to time the financing based on broader financial market conditions. In particular, the Corporate structure can be used as an interim measure, with the option of a later partial refinancing via the capital markets using other financing structures such as the "pay-as-you-go" or leveraged portfolio financing structures (not covered in this article).

Developers using this structure most commonly are large, financially strong, and have significant and predictably recurring income tax obligations. They have the cash flow to undertake the full investment and the ability to utilize the Tax Benefits in the years in which they are generated by the project. They also typically have strategic reasons to be investing in the wind sector, and view it as a core part of their business plan, rather than simply a convenient means to reduce tax burden. In effect, they are Strategic Investors that prefer to maintain full ownership without any other investors. FPL Energy - which owned more than one-third of all wind power capacity in the U.S. at the end of 2006 - is the most prominent example, as it has used this structure to finance the initial costs of most of its wind projects. A few other developers initially used this structure for some projects, but then shifted to other financing structures after their ability to make efficient use of the Tax Benefits changed.

The recent entry of several large foreign developers into the U.S. market and the related consolidation of the sector by financially strong players suggest that the Corporate structure will continue to be widely utilized going forward. At the same time, it will increasingly be employed not as the final structure, but rather as an interim means to get wind projects built and into operation pending later refinancings. To the extent that the foreign entities using this structure have insufficient U.S. tax appetite, such refinancings likely will involve Tax Investors.

Although the Corporate structure is the most commonly utilized structure in the U.S. (at least in terms of the amount of installed capacity), only a handful of large developers have been able to 
make use of it. Most other developers have found it useful or necessary to tap third-party equity or debt capital to finance their projects and monetize Tax Benefits. We turn now to those structures that enable them to do so, while still retaining an ownership stake in the project.

\subsection{Strategic Investor Flip}

The Strategic Investor Flip structure was one of the first structures used in the wind industry to attract third-party equity able to utilize the Tax Benefits, while allowing the developer to retain an interest in the project. It is also the simplest of the structures involving equity from Tax Investors. The name of the structure reflects the fact that it has been used primarily by Strategic Investors seeking an active role in wind projects. The project developer negotiates a percentage ownership share by the Strategic Investor, and the initial allocation of project cash flows and Tax Benefits are proportional to the respective ownership interests of the parties. In effect, this partnership structure is similar to a basic 50/50 joint venture structure. However, three key elaborations set it apart from a conventional joint venture.

The first key difference is that the Tax Investor provides almost all of the project equity, and in turn is initially allocated almost all of the cash and Tax Benefits. For example, with an undercapitalized developer, the Tax Investor might contribute equity for up to $99 \%$ of the total project cost, while the developer provides the remaining $1 \%$. Under this structure, the Tax Investor and developer are initially allocated the same respective $99 \%$ and $1 \%$ shares of the distributable cash and Tax Benefits (Revenue Procedure 2007-65 [3] requires the developer to have at least a $1 \%$ interest in the project's Tax Benefits).

The second elaboration involves the concept of a "flip" in the percentage allocations of the project cash flows and Tax Benefits once the Tax Investor has reached a pre-negotiated IRR on its investment (the "Flip Point"). This Flip Point is usually projected to occur on or shortly after the tenth anniversary of the project's commercial operation date, since the PTC is available only during the first ten years of operations. Since developers using this structure typically do not have the ability to utilize Tax Benefits efficiently, they do not want the flip to occur prior to the end of year ten.

After the Flip Point, the percentage allocations of project cash flow and Tax Benefits change to a second set of numbers that allocate most project flows away from the Tax Investor in favor of the developer. Although the Flip Point and the pre- and post-flip allocations are negotiated by the two parties, Revenue Procedure 2007-65 [3] dictates that the Tax Investor's minimum allocation of Tax Benefits (e.g., post-flip) should never be less than 5\% of the Tax Investor's maximum allocation of Tax Benefits. Thus, continuing with the example of a $99 \% / 1 \%$ pre-flip allocation, the Tax Investor's minimum post-flip allocation would be $4.95 \%$ (i.e., $5 \%$ of $99 \%$ ). It may, however, be necessary to allocate more of the post-flip flows to the Tax Investor to achieve its overall twenty-year IRR target, which is negotiated between the parties. It is also possible to have a second, later, Flip Point and to have the inversion of the percentage allocations be staged across the two Flip Points. For example, a transaction could include an initial 99\%/1\% allocation that flips to $20 \% / 80 \%$ on the first Flip Point and then to 5\%/95\% at the second Flip Point. 
The third difference, relative to a traditional joint venture, is that the Strategic Investor Flip structure often includes an option for the project developer to purchase the ownership interests held by the Tax Investor after the Flip Point. Revenue Procedure 2007-65 [3] requires that the purchase price must be based on fair market value determined at the time of the purchase, and that the purchase may not occur during the project's first five years. This 5-year requirement is not restrictive, since the purchase option is typically structured to first be available on or after the Flip Point has been reached - i.e., at the end of 10 years. The reduction in the Tax Investor's allocations after the Flip Point serves to reduce the fair market value of the Tax Investor's ownership interests and, consequently, the price that the developer must pay for such interests.

Figure 3 provides a schematic representation of the Strategic Investor Flip structure. Specifically, the schematic shows the relative percentage equity contributions from the project developer and the Tax Investor into the project company to fund initial construction costs (project-level term debt financing is not used). The shaded percentage boxes show the pre- and post-flip allocations of cash flow and the various Tax Benefits back to the developer and the Tax Investor. The first percentage in each box is the pre-flip allocation to each party, while the percentage after the forward slash represents the post-flip allocation. Although broadly representative (and compliant with Revenue Procedure 2007-65 [3]), in actual practice these percentages will vary from project to project and should therefore be considered merely illustrative.

This structure is useful for those project developers lacking both the financial strength to fund initial capital costs and the appetite for the Tax Benefits, but who are nonetheless unwilling to simply sell the project outright. Such developers typically have a business plan that calls for them to evolve into larger entities over time. They are not content simply to receive a single upfront development fee, but wish to develop a pool of projects that will generate cash flow over time.

For their part, Tax Investors can be attracted to this structure as it enables them to partner with capable, if cash-poor, project developers. The structure gives preferred return rights to the Tax Investor and, in so doing, allocates much of the risks of a wind project to the developer. If the wind resource proves weaker than first thought, if turbine technical availability proves less than promised, or if maintenance costs are higher than projected, the effect on the Tax Investor is mitigated by the fact that it is receiving virtually all of the cash flows and Tax Benefits that are generated by the project until the Flip Point, and the Flip Point will be delayed until the Tax Investor reaches its IRR target. ${ }^{3}$ This structural risk mitigant can be very attractive to potential Tax Investors just entering the market and desiring to reduce the risk of solitary investments.

Though employed for a few transactions earlier in the decade, the Strategic Investor Flip structure does not appear to be in frequent use currently (although some developers of smaller "community wind" projects are using versions of this structure). As described above, it has elements of interest to both Tax Investors and developers, but there are limitations. For developers, this structure obliges them to wait ten or more years to receive any substantive cash flow (other than through whatever up-front development fee is feasible given the project economics and any ongoing management fees charged by the developer for overseeing project 
operations). Other financing structures, including the Institutional Investor Flip structure described next, have since been developed that meet the developer's needs more effectively.

\subsection{Institutional Investor Flip}

The Institutional Investor Flip Structure is similar to the Strategic Investor Flip structure, in that the project developer brings in a separate Tax Investor to use the Tax Benefits, there is a Flip Point at which the allocations of cash and Tax Benefits change, and the developer typically has a purchase option exercisable after the Flip Point.

Beyond these similarities, there are several important differences. First, the name of the structure reflects the fact that it was devised to bring in less-active, more-passive equity capital from Institutional Investors. Second, in contrast to the Strategic Investor Flip, the initial allocations of cash and Tax Benefits are not proportional to each investor's respective equity contributions.

Specifically, in exchange for the developer contributing a greater portion of the initial equity capital (e.g., $30 \%$ - 40\% of the total), all of the distributable cash from the project is initially allocated to the developer until it recovers its capital. This typically takes place over the first four to six years of the project. After the developer has recouped its initial investment, $100 \%$ of the cash is then allocated to the Tax Investor until the Flip Point is reached.

Separately, the Tax Benefits are initially allocated in a 99\%/1\% sharing ratio in favor of the Tax Investor (Revenue Procedure 2007-65 [3] requires that the developer maintain at least a 1\% interest in the project's Tax Benefits). Once the Flip Point has been reached (again, on or shortly after the end of year ten), a majority of both the cash and Tax Benefits, typically around 90\%, are allocated to the developer.

Figure 4 provides a schematic representation of the Institutional Investor Flip structure. Initially all cash goes to the developer until it recoups its investment in the project company; thereafter, all cash goes to the Tax Investor until it reaches its target return, at which point a flip in the allocation of both cash and Tax Benefits occurs. This structure does not include any limitedrecourse project debt financing.

The Institutional Investor Flip structure was developed to address limitations of the Strategic Investor Flip for various types of developers and investors. Specifically, some developers have capital to invest and the interest in doing so, but lack the ability to use the Tax Benefits. For such investors, the Strategic Investor Flip, with its proportional link between the percentage of equity invested and receipt of cash and Tax Benefits, does not provide the means to invest capital without being saddled with unwanted Tax Benefits. The Institutional Investor Flip addresses this issue with disproportionate allocations of cash and Tax Benefits.

Many Institutional Investors like this structure because it obliges the project developer to invest more capital than under the Strategic Investor Flip, thereby becoming more vested in the success of the project. To date, tax-oriented Institutional Investors active in the wind sector have been comprised primarily of banks and insurance companies, including JPMorgan Capital 
Corporation, GE Financial Services, Wells Fargo, Morgan Stanley, Union Bank of California, New York Life, Prudential, Wachovia Securities, and U.S. affiliates of AEGON, NV, among others. These investors have experience with other tax-oriented investments (e.g., low-income housing), and seek the additional return offered by wind projects.

More recently, this structure has facilitated the entry of cash-based investors ("Cash Investors") i.e., those with a preference for a cash-based return as opposed to one comprised primarily of Tax Benefits - into the wind sector. Some Cash Investors have similar strategic goals as Strategic Investors, but lack the tax capacity to use all of the Tax Benefits; examples include foreign utilities entering the U.S. market, such as Enel and Iberdrola. ${ }^{4}$ Alternatively, some Cash Investors are more akin to Institutional Investors, but lack tax appetite; examples include Babcock \& Brown Wind Partners and ArcLight Capital.

For such Cash Investors (i.e., those that invest alongside the developer), the Strategic Investor Flip structure is not suitable, since it would require only a small amount of capital and not provide a substantive share of the cash flow until after the Flip Point. In contrast, the Institutional Investor Flip structure enables a Cash Investor to put more capital to work, and to receive a preferred cash flow early in the project, thereby both reducing its longer-term exposure, while also recycling funds to support new wind projects. In some cases, these Cash Investors team with undercapitalized developers to jointly act as the project sponsor. In other cases, the Cash Investors have acquired either the project development rights or simply acquired the smaller developer outright so as to become the sole project sponsor.

In aggregate, these attributes have made the Institutional Investor Flip the preferred financing structure for those developers seeking third-party financing (and not simply selling their projects outright). Of the 13 transactions involving Tax Investors reported closed from 2003 through 2005 , ten used this structure. It remained a popular structure in 2006. Such repeated use has spurred increasing comfort with this structure, as well as some standardization of transaction documentation.

\subsection{Back Leveraged}

The Back Leveraged structure is the same as the Institutional Investor Flip structure, but with a layer of debt outside of the project company at the level of a holding company for the interests of the developer. The developer pledges its ownership interests in the project company to secure the debt, and uses the debt to fund part of its initial capital contribution. As the debt is at the developer level, it does not have an impact on the economics at the level of the project company. The debt provider has no recourse to the project company, other than via the pledge of the developer's equity share interests. The underlying structure and allocations to each party remain the same as in the Institutional Investor Flip structure. Loan covenants typically include provisions to sweep excess developer cash flow to make loan prepayments. As a result, while the nominal loan maturity may be as long as 15 years, the effective maturity often is significantly shorter, e.g., as short as four to six years.

Figure 5 provides a schematic representation of the Back Leveraged structure. Specifically, the schematic shows the relative equity contributions from the project developer (which in turn, is 
partly financed by back leverage) and from the Tax Investor into the project company to fund initial construction costs, as well as pre- and post-flip allocations of cash flows and Tax Benefits to each party. The developer repays its borrowed equity stake out of the cash flow allocated to it.

The Back Leveraged structure is becoming more common in the market. It is increasingly being used by developers interested in using debt - either to boost their long-term rate of return, or to increase their equity participation in a project - but desiring to keep the direct project assets unencumbered (to please Tax Investors, as discussed in the next section). Tax Investors are not impacted by this financial engineering at the developer level; indeed, they may not participate in or even see the loan documentation. As such, this structure satisfies the Tax Investor market preference for all-equity projects.

\subsection{Cash Leveraged}

The Cash Leveraged structure is based on the same underlying structure as the Strategic Investor Flip structure (at least in a mechanical sense, with proportional allocations), ${ }^{5}$ but features a layer of debt added at the project level (rather than at the developer level, as in the Back Leveraged Structure). The loan is provided on a limited-recourse basis. Accordingly, it is sized to be repaid from the cash flow generated by the project and is secured by the project's assets. The initial percentage equity funding contributions by the developer and the Tax Investor are the same as with the all-equity Strategic Investor Flip, but the amount of the initial equity capital required is reduced by the amount of the debt. In turn, the loan principal and interest payments reduce the amount of distributable cash available to the investors.

The percentage of debt varies across projects, but is commonly around 40-60\% of total project costs. For any given project, the size of the loan is a function of the projected cash flows and loan terms. The most important loan terms are the tenor (i.e., the number of years the loan is scheduled to be outstanding), the interest rate, and the debt service coverage ratio ("DSCR"), which typically requires wind projects to generate operating cash flows equal to at least 1.45 times the debt service in each period. In exchange for providing low-cost capital, the lender will have a first lien on the project assets, first rights to cash generated, and approval rights with respect to major operating decisions.

Figure 6 provides a schematic representation of the Cash Leveraged structure. Specifically, the schematic shows the relative contributions from the project developer, the Tax Investor, and the lender into the project company to fund initial construction costs, as well as pre- and post-flip allocations of cash flows and Tax Benefits to each party. Debt service payments are deducted from the cash flows, with the residual distributed to the developer and Tax Investor. In addition, interest payments on the debt are tax-deductible, thereby increasing taxable losses (or, in later years, reducing taxable gains).

Developers seek limited-recourse project debt for two principal reasons: to boost equity returns (through the use of lower-cost capital) and to reduce required equity contributions. The former may be important for some projects where the returns otherwise are marginal or unattractive. This might occur, for example, if a project is in a marginal wind regime, or has been obliged by local market conditions to accept a lower-than-desired power purchase price. ${ }^{6}$ 
Developers seeking project debt often have a general corporate strategy of minimizing their capital investments in individual transactions. They are comfortable in their ability to access debt efficiently and to work through Tax Investor concerns over lender covenants (discussed below). These are typically developers with prior experience in using debt, perhaps in conventional power projects. Developers who have tapped term debt include Invenergy Wind, UPC Wind, enXco, and Noble Environmental Power.

The use of debt on a project can, however, limit the pool of Tax Investors that are willing to invest. Some Tax Investors do not want to have to contend with a lender in case a project encounters financial stress. Specifically, they fear the loss of their equity investment if a lender elects to foreclose on the project company. The potential for such an "equity squeeze" can arise since their interests in the project company are usually pledged to the lender as part of the collateral for the loan. Such Tax Investors prefer to retain the flexibility of contributing additional funds to support a project in distress without having to coordinate such support with a lender. For these investors, the additional transaction costs and controls associated with debt outweigh the lower cost of capital. The additional time that it takes to close on debt financing relative to an all-equity deal may also be an issue for some investors, particularly if the PTC is nearing expiration. In contrast, other Tax Investors are comfortable with having debt at the project level, believing that the lender's due diligence and ongoing monitoring of project operations are likely to result in better-structured deals that reduce their own risks. Tax Investors who have invested in wind transactions involving leverage at the project level include the Union Bank of California, AEGON-affiliated life insurance companies, and JP Morgan.

Due largely to the Tax Investor concerns described above, levered structures (i.e., those with debt at the project level) have been in the minority for financing wind projects in the U.S. Although term debt has been used in the market, the all-equity structures (including Back Leverage) described previously are more common. ${ }^{7}$ Short-term turbine supply loans and construction loans have been used more frequently than term debt, but these are replaced by equity upon the project commencing operations.

\subsection{Cash \& PTC Leveraged}

The Cash \& PTC Leveraged structure is the same as the Cash Leveraged structure but with an additional layer of debt - based on expected PTCs - at the project level. As a tax credit used by the project owners, the PTCs do not generate cash at the project level that can be used to repay project-level debt. Thus, the debt service payments of the additional debt will eat into (and sometimes exceed) the cash flow cushion created by the DSCR for the cash-based loan. In response, lenders typically require that the Tax Investor provide a contingent guarantee to make periodic additional equity investments into the project company on an as-needed basis. The amount of such injections for any period is capped at the amount of PTCs actually generated in that period (or, in some cases, the actual debt service payment shortfall - whichever is lower). Lenders usually focus on the credit-worthiness of the guarantee by the Tax Investor, since the Tax Investor makes the lion's share of the equity contributions (e.g., 99\%) under this structure. On occasion, lenders will seek such commitments from the developer as well as the Tax Investor. ${ }^{8}$ Such injections essentially create a second contingent cash flow stream that lenders 
are willing to rely upon to support an incremental PTC loan. With this incremental source of project-level cash flow, projects using the Cash \& PTC Leveraged structure can support debt for up to $50 \%$ to $65 \%$ of total project costs, compared with the $40 \%$ to $60 \%$ levels under the Cash Leveraged structure.

Figure 7 provides a schematic representation of the Cash \& PTC Leveraged structure. Debt service payments - for both the Cash and PTC tranches - are paid from project cash flows prior to allocating the residual cash flow to the developer and Tax Investor. Interest payments on the debt are tax deductible, thereby increasing taxable losses (or, in later years, reducing taxable gains). To the extent that there is not enough cash to repay the PTC debt, the Tax Investor and (sometimes) the developer make proportional equity contributions into the project company; these incremental contingent contributions are shown as dotted arrows parallel to their original equity contribution arrows.

Developers considering the Cash \& PTC Leveraged structure are particularly comfortable with using debt to leverage their equity investment and believe that the return boost from the incremental PTC debt merits the added complexity. However, the inclusion of a PTC tranche of debt limits the pool of potentially interested Tax Investors still further, because few Tax Investors have been willing to assume the contingent obligation surrounding future capital contributions.

When judging a project opportunity, an investor will compare the expected rate of return against its cost of capital. This evaluation becomes problematic with an obligation to fund uncertain amounts at unknown dates in the future, as far out as ten years from the present. Because there is generally great uncertainty about future cost of capital and even availability of funds, many Tax Investors prefer the certainty of making just one initial investment over making an initial investment and a series of potential future contributions. As a result, few Tax Investors are willing to guarantee to provide ongoing equity contributions in support of a PTC loan monetization. In addition to concerns about a lender squeezing out their equity interest in the event of project difficulties, they dislike the obligation to potentially make ongoing contributions in support of a loan - particularly if the project is not performing well (i.e., when such contributions are most likely). Given such issues, relatively few Tax Investors have proved willing to sign up for this structure.

As a result, this type of structure, involving both a Tax Investor separate from the developer and a PTC loan, is rarely seen in the market. Two different developers each used this structure to finance a project in 2002 and 2004. Invenergy Wind also used a version of the structure to finance a portfolio of three projects in 2005 [5]. No other such transactions are believed to have been done. As loan documentation and terms are worked out that address Tax Investor concerns, however, there are indications that this structure may be utilized for some projects in 2007-08.

\section{Choosing a Structure}

Project developers typically make the decision on which of the financing structures described in this article best meets their needs for a given project based on a number of considerations. The decision reflects both the developer's own ability to use the Tax Benefits and to provide the 
capital funding, as well as the financial robustness of the project itself, e.g., whether debt leverage is needed to boost projected returns to satisfy return requirements. Earlier in the decade, the amount of time before the next expiration of the PTC also played a role, as some developers adjusted their project development and financing strategies so as to increase the prospects of meeting PTC deadlines. As this pressure has abated more recently (i.e., developers have become more confident that the PTC will be renewed), the number of financing options being created and used has increased. Secondary factors also influence the financing decision, e.g., the relative preference for realizing value up-front via a development fee or capital gain on sale of the project, or over time from the net cash flows from operations.

The relative importance of these various considerations differs from developer to developer and from project to project. Furthermore, some developers' preferred financing structures have evolved over time, particularly as their own financial situations have changed. In short, there is no single "correct" structure for all developers for all projects for all time.

Notwithstanding the above, one can illustrate, in general, the varied rationales for each financing structure by looking at the (hypothetical) decision process facing wind developers in choosing a financing structure. Table 1 provides a list of several key corporate and project-level considerations, grouped into six scenarios that represent differing combinations of these considerations. Depending on a given developer's views on each consideration, one or more financing structures (identified in the final column) are likely to be more suitable than other structures to meet the needs of the developer. It is important to note that the table is generalized and focuses on just a few key considerations; other factors can lead a developer to opt for a different financing structure than that suggested in the table.

Scenario 1 typifies smaller developers lacking the financial or technical wherewithal to carry a project through construction into operation. Such developers commonly adopt a business strategy that focuses on early project development, with the goal being to sell their projects to larger entities prior to construction. Earlier in the decade, this was the only real alternative for developers unable to carry their own projects into operation.

Scenario 2 portrays a simple Corporate structure, where the developer has the financial resources to fund the project, efficiently use the Tax Benefits, and desires a long-term ownership stake for strategic reasons. This is the most common wind project financing structure in the United States (in terms of installed capacity), though only a handful of large developers are able to make use of it.

Scenarios 3 and 4 pertain to all-equity flip structures, where the developer cannot fully fund the project or use its Tax Benefits, but nevertheless desires a long-term ownership stake in the project. The Strategic Investor Flip structure (Scenario 3) may be useful for developers with limited or no long-term capital to invest and not needing significant early cash flows.

If instead the developer has some cash to invest but would like to recoup its investment, in cash, sooner than possible under the Strategic Investor Flip structure, then the Institutional Investor Flip structure (Scenario 4) may be more useful. This scenario also may make sense if the developer has received equity financing from sources unable to use the Tax Benefits, to the 
extent that such sources (e.g., pension funds or other Cash Investors) also want to see significant cash distributions earlier than available under the Strategic Investor Flip structure. If such a developer desires to finance a portion of its capital investment (either to preserve cash or boost returns) using "back leverage," then Scenario 5 - the Back Leveraged structure - is a relevant structure.

Scenario 6 represents a leveraged version of Scenario 3, where the intent is to boost project IRRs. The choice of which leverage structure to use generally reflects the relative project economics, i.e., whether the incremental PTC monetization is needed to achieve requisite equity returns. It can also reflect other factors, such as the relative interest of Tax Investors in the specific project and the incremental contingent financial obligations associated with PTC debt. For reasons already discussed, the use of leverage at the project level has been relatively uncommon over the past few years, but may become more common in the future.

As noted, these scenarios are simplified to illustrate key differences. Specific developers likely will have additional or other considerations in connection with specific projects or with their overall corporate goals that will impact the choice of financing structure. Other permutations of the various considerations identified here also are possible.

\section{Conclusions}

The U.S. wind power sector has grown significantly in the last decade. The pace of sector development has outstripped the ability of most developers to fund project capital costs and to make efficient use of project Tax Benefits. In response, the sector has been successful in creating novel project financing structures to attract both Strategic and Institutional Investors. Even in the short period since 1999, however, these structures have risen and declined in relative popularity, based on the evolving needs of both developers and new investors in the wind sector. As the market continues along its path of strong growth, existing financing structures will continue to evolve, and new structures will no doubt be developed to meet the emerging needs of the market. 


\section{References}

1. Harper, John, Matt Karcher, Mark Bolinger. 2007. Wind Project Financing Structures: A Review \& Comparative Analysis. LBNL-63434. Berkeley, Calif.: Lawrence Berkeley National Laboratory. Accessed June 23, 2008 at http://eetd.lbl.gov/ea/emp/reports/63434.pdf

2. Wiser, Ryan, and Mark Bolinger. 2008. Annual Report on U.S. Wind Power Installation, Cost, and Performance Trends: 2007. DOE/GO-102008-2590. Washington, DC: U.S. Department of Energy, Office of Energy Efficiency and Renewable Energy. Accessed June 23, 2008 at http://eetd.lbl.gov/ea/ems/reports/lbnl-275e.pdf

3. Internal Revenue Service (IRS). 2007. Revenue Procedure 2007-65. Listed on pages 967-969 of Internal Revenue Bulletin 2007-45. November 5, 2007. Accessed June 23, 2008 at http://www.irs.gov/pub/irs-irbs/irb07-45.pdf

4. Eber, John. 2008. Remarks made during the "Financing Options and Structures" panel discussion at WINDPOWER 2008. Houston, Texas, June 2, 2008.

5. Murphy, James. 2005. "Invenergy Wind Finance Company Portfolio Financing Transaction." Invenergy, LLC, presentation at Renewable Energy Finance Forum, June 23-24, 2005, organized by Euromoney and American Council on Renewable Energy. Accessed June 23, 2008 at http://www.acore.org/programs/05_reff_presentations/05_REFF_Murphy.pdf 


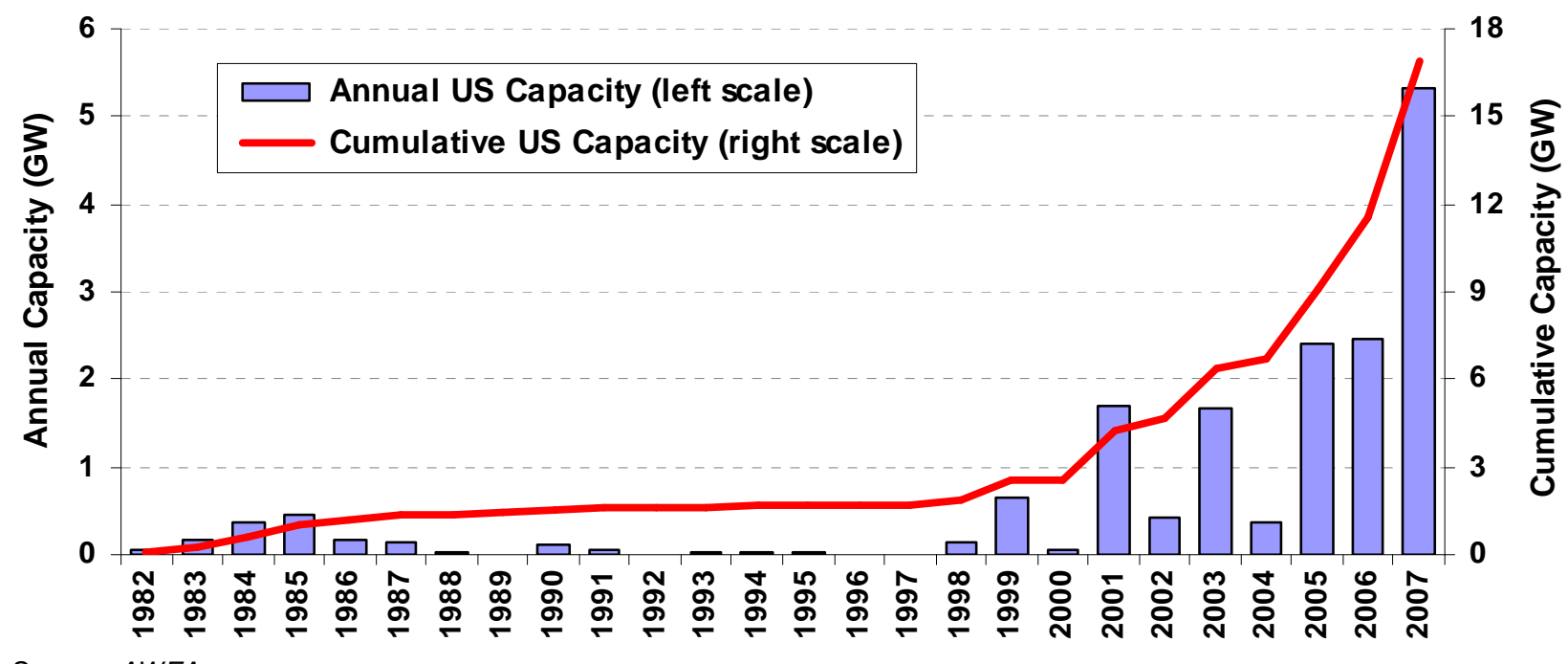
Source: AWEA

Figure 1. Annual and Cumulative Growth in U.S. Wind Power Capacity 


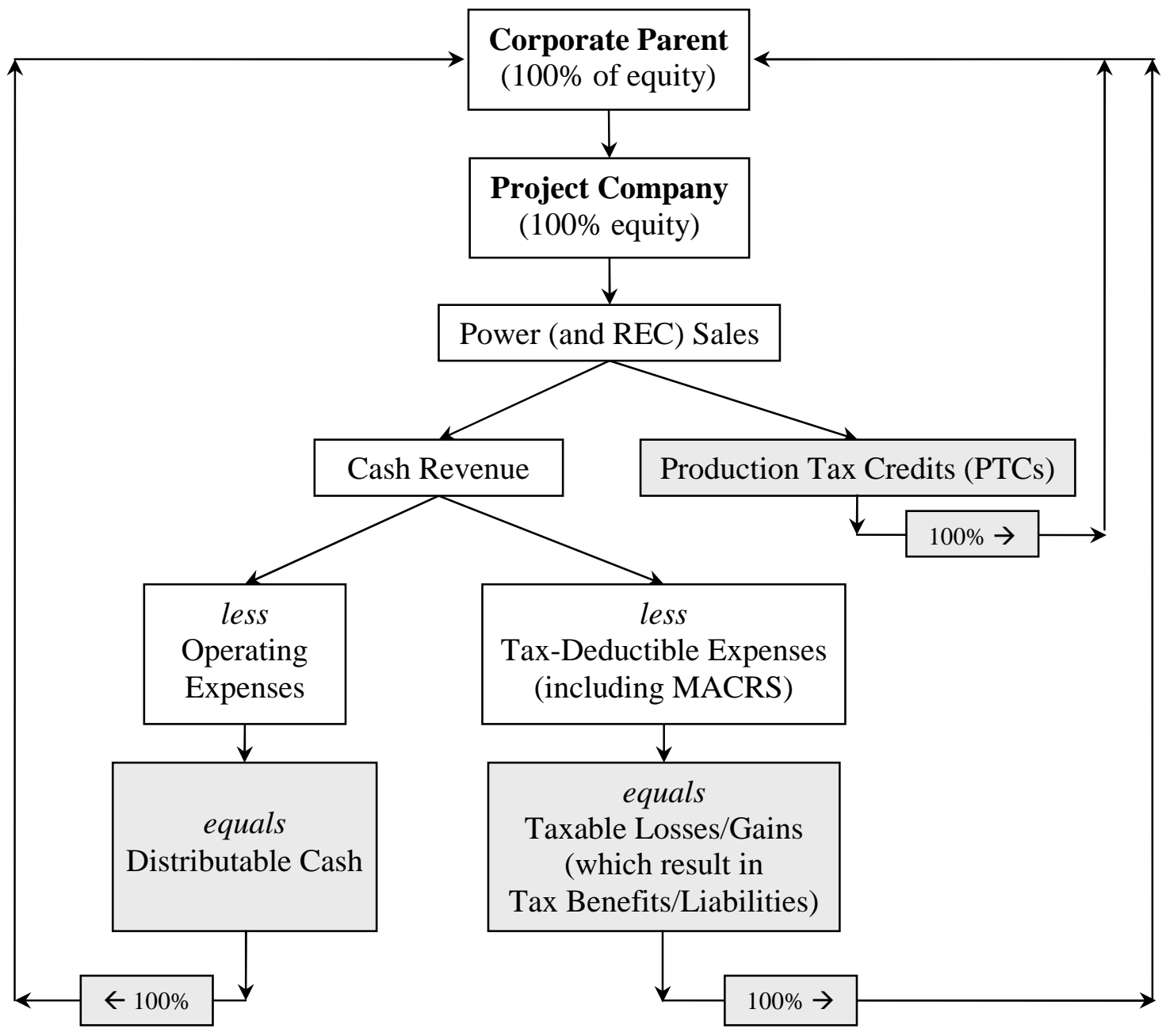

Figure 2. Schematic of Corporate Structure 


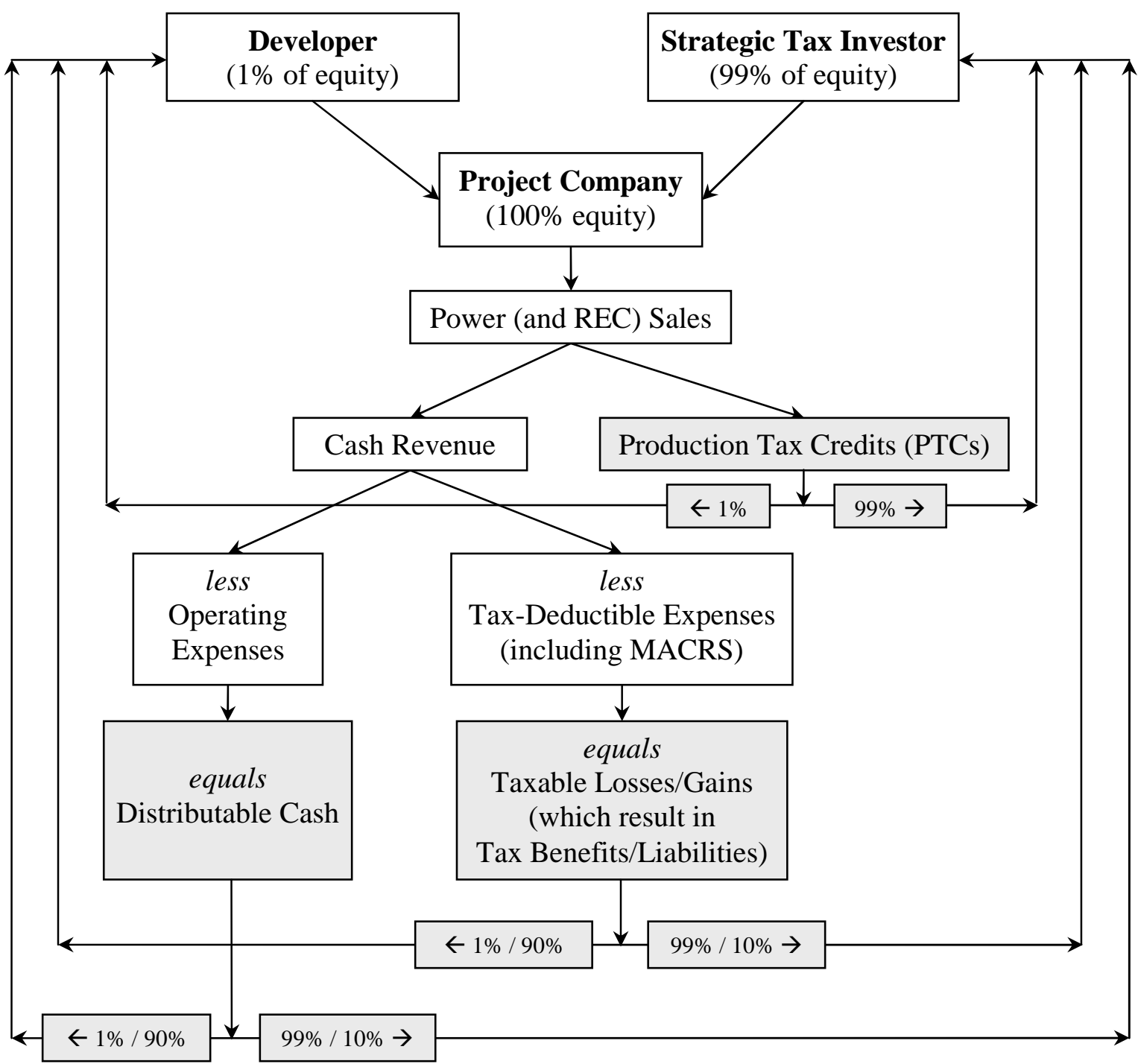

Figure 3. Schematic of Strategic Investor Flip Structure 


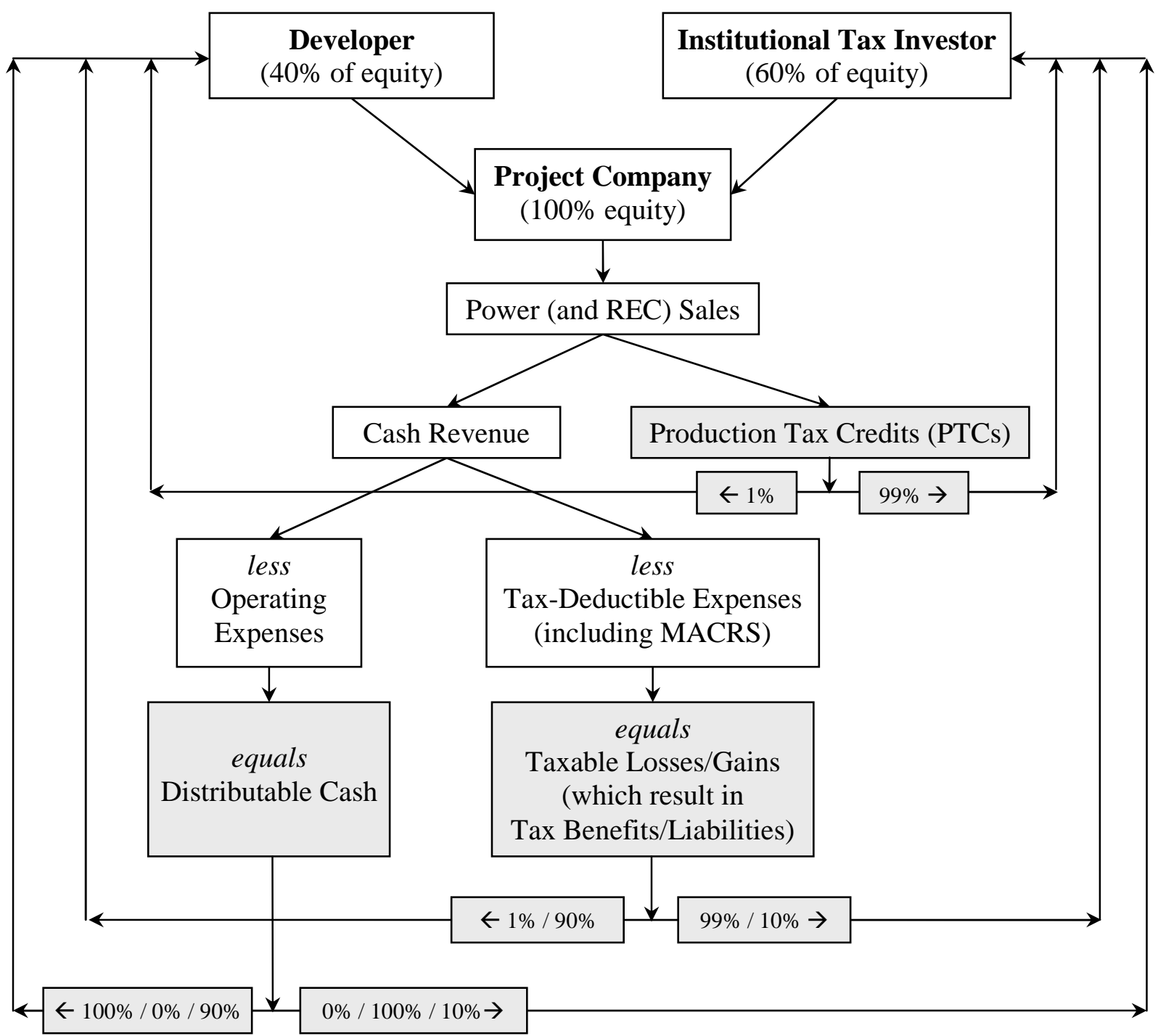

Figure 4. Schematic of Institutional Investor Flip Structure 


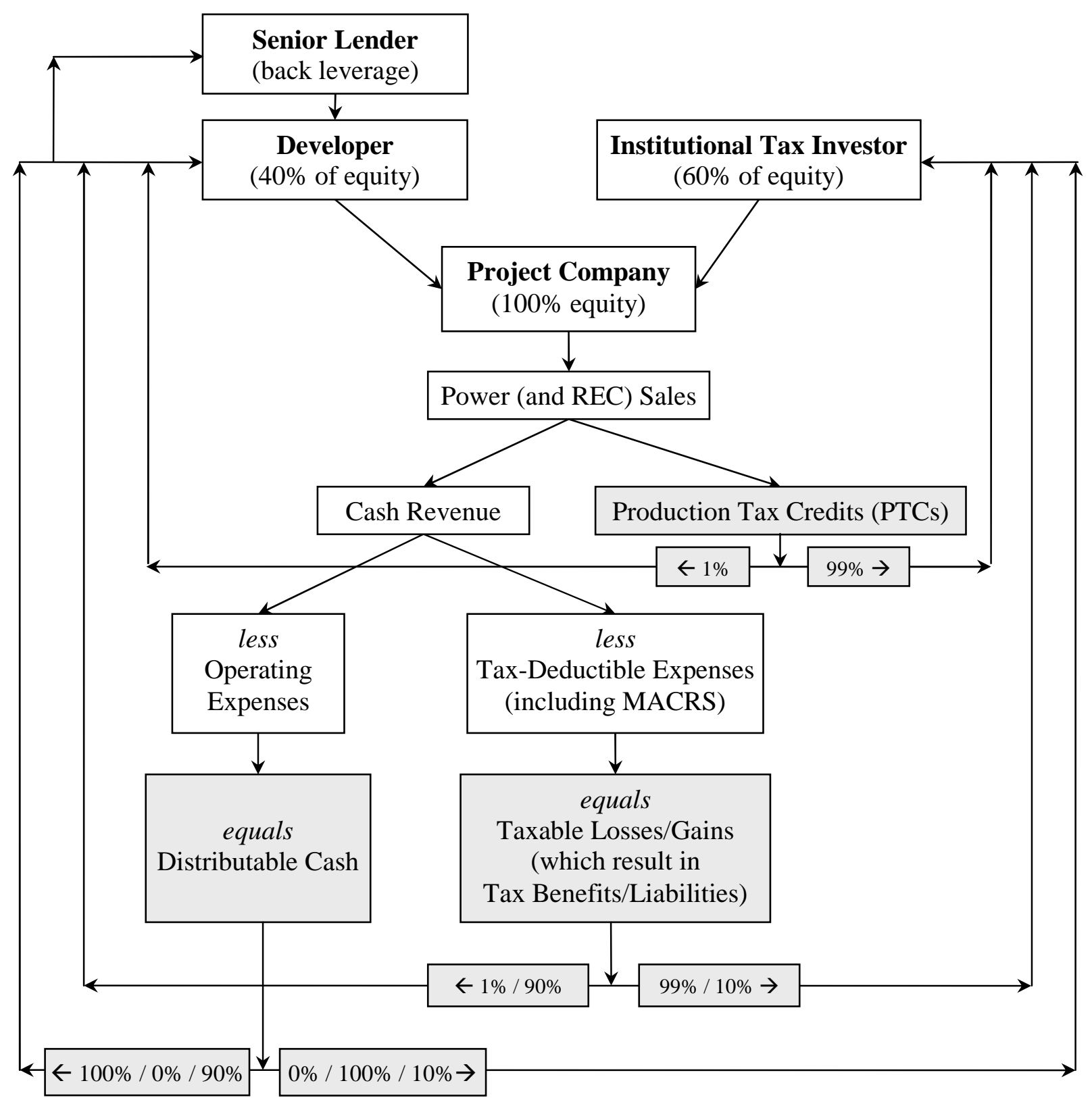

Figure 5. Schematic of Back Leveraged Structure 


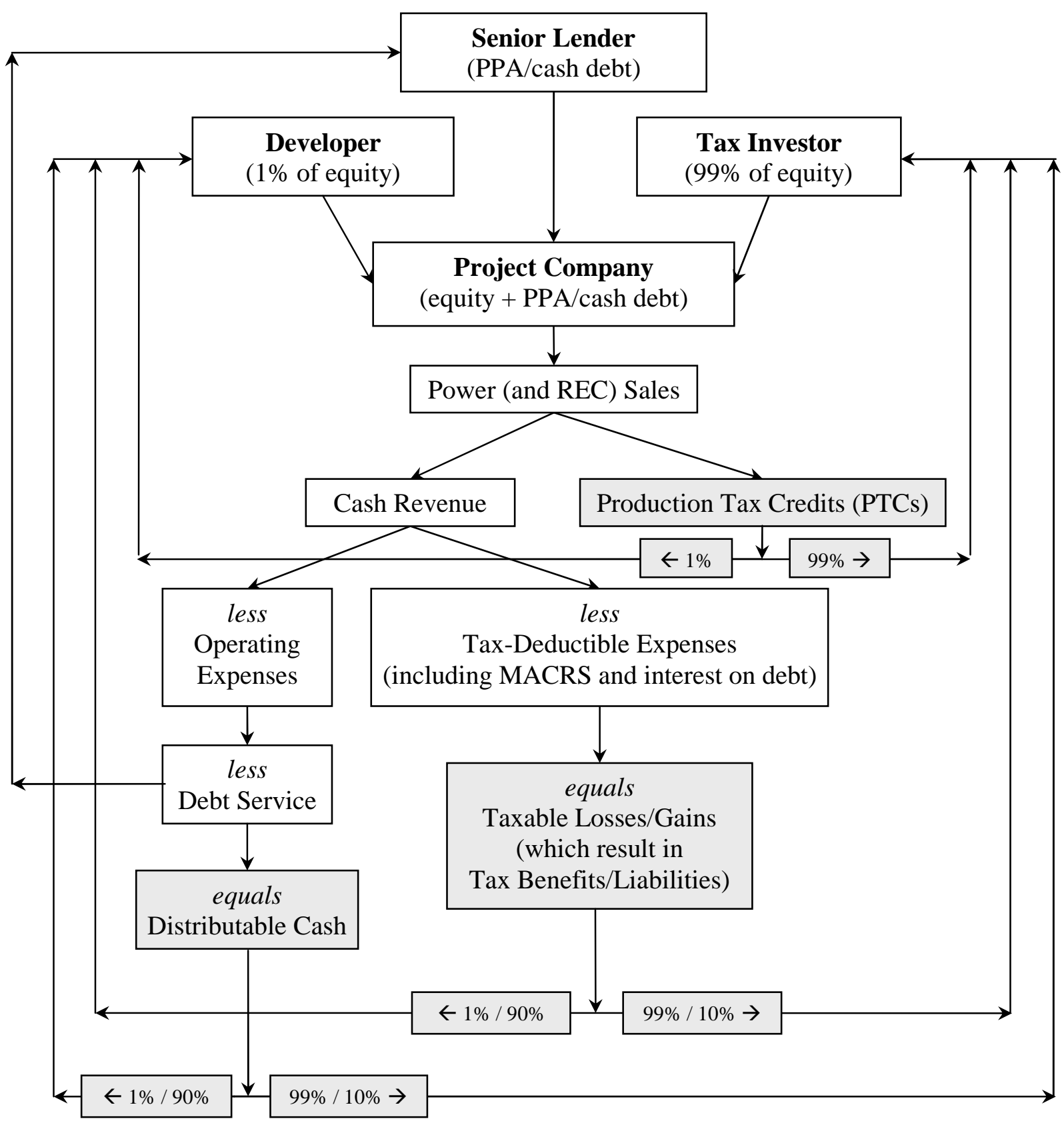

Figure 6. Schematic of Cash Leveraged Structure 


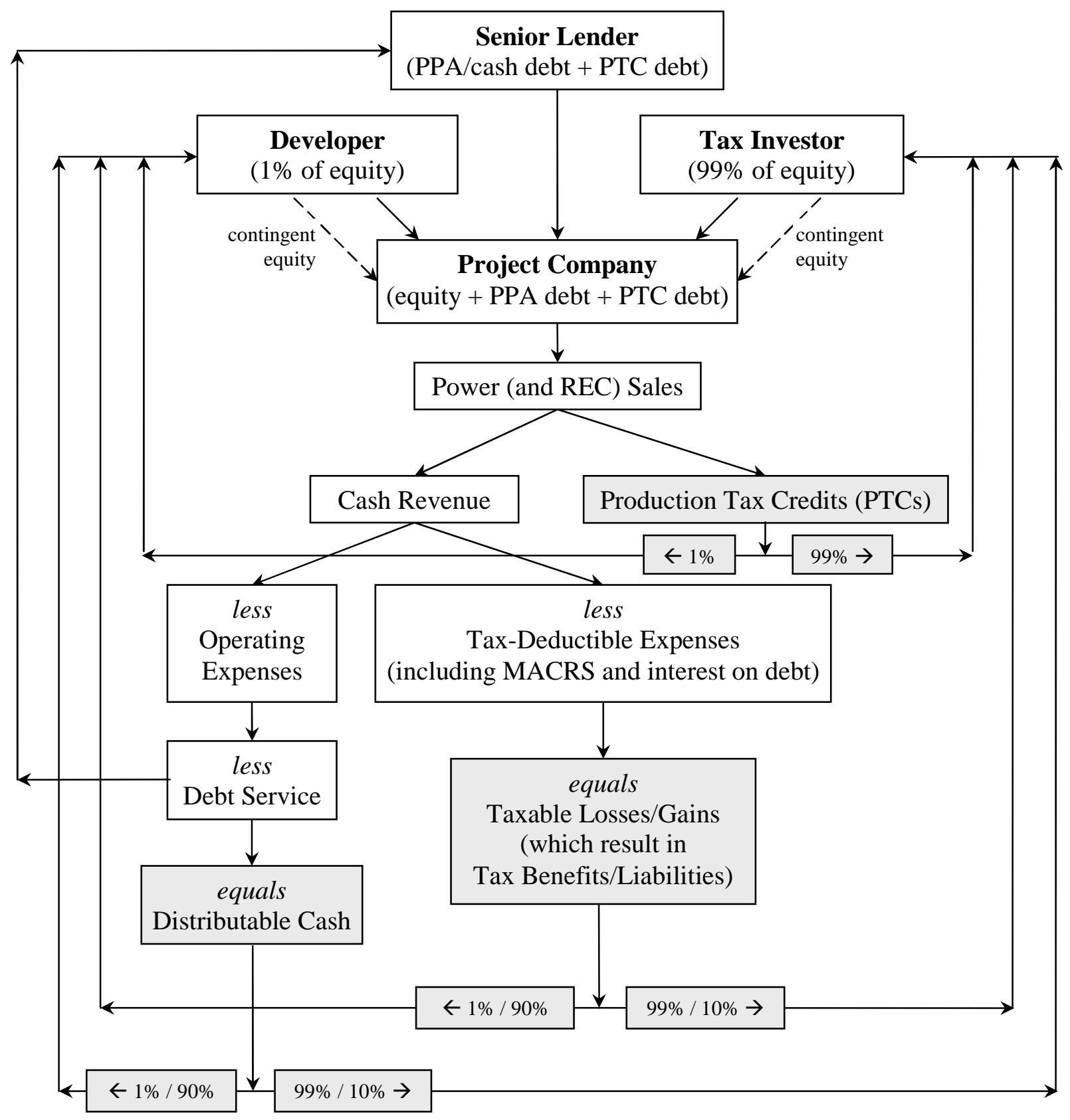

Figure 7. Schematic of Cash \& PTC Leveraged Structure 
Table 1. Wind Developer Financing Structure Decision Matrix

\begin{tabular}{|c|c|c|c|c|c|c|}
\hline Scenario & $\begin{array}{c}\text { Developer } \\
\text { can use } \\
\text { Tax Benefits }\end{array}$ & $\begin{array}{c}\text { Developer } \\
\text { can fund } \\
\text { project costs }\end{array}$ & $\begin{array}{c}\text { Developer wants } \\
\text { to retain stake in } \\
\text { project ownership / } \\
\text { ongoing cash flows }\end{array}$ & $\begin{array}{c}\text { Developer } \\
\text { wants early } \\
\text { cash } \\
\text { distributions }\end{array}$ & $\begin{array}{c}\text { Project } \\
\text { has low } \\
\text { projected } \\
\text { return }\end{array}$ & $\begin{array}{c}\text { Most suitable financing } \\
\text { strategy or structure: }\end{array}$ \\
\hline 1 & No & No & No & Yes & N/A & $\begin{array}{c}\text { Sell project to a } \\
\text { Strategic Investor }\end{array}$ \\
\hline 2 & Yes & Yes & Yes & No & No & Corporate \\
\hline 3 & No & Limited & Yes & No & No & Strategic Investor Flip \\
\hline 4 & No & Limited & Yes & Yes & No & Institutional Investor Flip \\
\hline 5 & No & Limited & Yes & Yes & Yes & Back Leveraged \\
\hline 6 & No & Limited & Yes & No & Yes & $\begin{array}{c}\text { Cash Leveraged or } \\
\text { Cash \& PTC Leveraged }\end{array}$ \\
\hline
\end{tabular}




\section{Endnotes}

${ }^{1}$ Renewable energy credits, or RECs, represent the renewable or environmental attributes associated with each MWh of renewable generation, and are often used to demonstrate compliance with state policy goals. RECs can either be bundled and sold with the electricity generated by the project, or alternatively stripped out and sold separately to create a second cash revenue stream.

${ }^{2}$ For example, developers continually explore different ways to use debt financing. Also, some developers initially finance a project using one structure, and then refinance it via another structure at a later date. Given this article's focus on project-level financing structures for new wind projects, those structures used primarily to refinance existing projects - including the "pay-as-you-go" structure and multi-project portfolio financings - are not covered. Harper et al. [1] provides more detail on these approaches, and in particular the "pay-as-you-go" structure.

${ }^{3}$ Note that this is not the same as the developer guaranteeing the Tax Investor's return, which is prohibited under Revenue Procedure 2007-65 [3]. If the project were to be severely compromised, the Flip Point could be delayed indefinitely, and the Tax Investor might never reach its return target.

${ }^{4}$ In July 2007, Iberdrola announced an agreement to acquire a utility in the Northeast. The acquisition may enable Iberdrola to use some Tax Benefits internally and thereby enable its wind project subsidiaries to use the Corporate financing structure for more projects for longer periods.

${ }^{5}$ The Strategic Investor Flip has been the basis for most leveraged wind transactions closed since 1999. A few transactions have used a basic joint venture structure (without a flip) or the Corporate structure as the base structure - i.e., they have not used third-party Tax Investor capital. The sponsor of a large transaction that closed financing in 2007 reportedly initially considered combining leverage with a version of the Institutional Investor Flip structure. Leveraging the Institutional Investor Flip structure presents a challenge, however, because making debt service payments leaves relatively little cash available for early allocation to the developer.

${ }^{6}$ Note, however, that a lower-than-desired power purchase price will not be able to support as much debt as would a higher power purchase price. Even so, any leverage that can be added to the project may boost returns.

${ }^{7}$ For example, one of the largest tax investors in the U.S. wind power market, JP Morgan, estimates that there were 18 wind transactions involving $\$ 5.2$ billion in tax equity that closed in 2007, and that only 2 of these 18 deals used project-level term debt. JP Morgan is expecting 25 wind transactions totaling $\$ 8$ billion in tax equity to close by the end of 2008, only 3 or 4 of which will use project-level term debt [4].

${ }^{8}$ For tax reasons, the developer may want to contribute its small percentage share regardless of the lender's requirements so as to preserve the relative allocations of the cash flows and Tax Benefits between the owners. 